\title{
Economic Effects of Avian Influenza on Egg Producers in Turkey*
}

Duthor(s)
Demircan $\mathrm{V}^{\text {***}}$
Yilmaz $\mathrm{H}^{1}$
Dernek $\mathrm{Z}^{1}$
Bal T1
Gül $\mathrm{M}^{1}$
Koknaroglu H ${ }^{2}$
Department of Agricultural Economics,
Faculty of Agriculture, Süleyman Demirel
University, Isparta-Turkey.
Department of Animal Science, Faculty
of Agriculture, Süleyman Demirel
University, Isparta-Turkey.

\section{Mail Address}

\author{
Vecdi Demircan \\ Department of Agricultural Economics \\ Faculty of Agriculture \\ Süleyman Demirel University \\ Isparta-Turkey \\ E-mail: vecdem@ziraat.sdu.edu.tr
}

\section{Keywords}

Avian influenza, economic analysis, laying hens.

* Supported by the Research Fund of Suleyman Demirel University (Project No. 1375-M-06)

\section{ABSTRACT}

This study determined the economic effects of avian influenza on the egg-production sector of Afyon Province, Turkey. Economic indicators were compared before and during the avian influenza outbreak. A questionnaire was conducted with 75 poultry farmers. Farms were divided into three groups according to their size. The profitability of the three farm size groups was compared during two study periods: before and during the avian influenza outbreak. The results indicate that, as compared to previous levels, farms experienced significantly reduced incomes during the avian influenza episode. While net income and profit margin were found to be negative in all three farm groups during the avian influenza period, only group I showed economic loss prior to avian influenza. Average net income per group was -19,576.14, -39,810.11, and $-112,035.33$ YTL respectively during the avian influenza outbreak, compared with prior incomes of $-5,665.51,8,422.92$, and 16,3873.71 YTL (1 USD=1.43 YTL). The profit margin per egg during avian influenza was $-0.029,-0.016,-0.010 \mathrm{YTL}$ in group I, II, III, respectively, as compared to $-0.007,0.003$, and 0.014 YTL/egg before avian influenza. It was found that, whereas larger farms were more profitable than small farms prior to the avian influenza period, larger farms suffered greater economic losses than small farms during avian influenza outbreak in the participating farms.

\section{INTRODUCTION}

Ensuring food safety should be primary focus of national agricultural policies, irrespective of the level of economic development of agriculture. As proteins of animal origin are an important part of many people's diets, meeting the demand for animal protein is a crucial part of the food safety policy. Turkey's rapidly increasing population presents some challenges in providing for balanced nutrition, and this situation requires rational use of resources in the national economy. Even though geographical and ecological conditions in Turkey favor animal agriculture, the level of production and consumption of animal products is not sufficient to fully supply the required protein level. It is evident that many people in Turkey do not currently consume sufficient animal protein. Thus, it has been recommended that measures should be taken to increase consumption of animal protein (State, 2001).

Chicken production has an important role in Turkey's animal production sector. It significantly contributes to the Turkish economy through employment and the economic value of its products. Chicken meat and eggs have a high nutritional value and short production times. The egg-production sector presents opportunities to improve dietary quality at a relatively low economic cost. For these reasons, the egg-production sector has a central role in terms of increasing 
Demircan V, Yilmaz H, Dernek Z, Bal T, Gül M, Koknaroglu H and developing animal production (Bayaner, 1999).

In recent years, important developments have been achieved in the egg-production sector in Turkey, particularly in terms of the number of hens, production, yields, production technology, and marketing cooperation. As a result of these developments, traditional village laying hens have been replaced by commercial and industrial-scale egg-production farms. Likewise, there was a 5.4 fold increase in the total number of hens in Turkey, from 64,078,000 in 1990 to 344, 819,845 in 2006. Between 1990 and 2006, egg production in Turkey increased from 384,930 to 733,348 ton/year, corresponding to a 1.9 fold increase. The total number of layers in Turkey in 2006 was $58,698,485$ in 2006 , representing $17 \%$ of the total laying hens (Turkish, 2006). According to 2006data, Turkey was ranked 11 th in the world in terms of egg production (Food, 2006). Although these data demonstrate the progress of this sector, hen farming has several problems and its current potential cannot be completely assessed. The production system is foreign-dependent in terms of genetics. Several technologically-dependent production processes (vaccines, antibiotics, biologic and chemical elements, feed additives, growth promoters, etc.), poultry houses, hatcheries, feed mills, and processing plants have also largely been supplied by overseas companies. In addition, several feed raw materials, especially maize and soybean, have been purchased from abroad. All these factors considerably increase production costs and negatively affect the international competitiveness of Turkish egg industry. The volatility of international egg prices, due to supply-demand instabilities, means that egg prices are sometimes lower than production costs. Such fluctuations have been identified as the most significant challenge for egg-producers (State, 2001).

The first confirmed cases of avian influenza in Turkey occurred in the Manyas district of Balikesir province. The spread of disease can generally be limited by following a series of containment measures, but, as these measures were not implemented in the entire country, avian influenza appeared in the Doğubeyazit district of Ağri province at the end of December in 2005. Across Turkey, 20 people were infected with avian influenza, 4 of whom died, and 2.5 million birds were destroyed (Yenen, 2006). The egg sector was considerably affected by avian influenza. Since the demand for chicken meat and eggs declined, producers experienced important economic losses. Producers had to sell their products below cost price, and some farms closed as a result (Demir, 2006). In the study area avian
Economic Effects of Avian Influenza on Egg Producers in Turkey

influenza was not observed, but it affected layer farms due to a reduction in egg demand in egg price. In the study area some preventive measure instructions were given to producers, who were required to follow them by municipalities and the Ministry of Agriculture and Rural Affaires. The preventive measures included entrance restrictions in layer farms, detailed sanitation measures, and preventing the access of wild birds into the poultry houses. The additional costs resulting from these measures were paid by municipalities and Ministry of Agriculture and Rural Affaires.

The purpose of this study was to determine the economic effects of avian influenza on layer farming in Afyon province, Turkey. Afyon province has an important role in egg production and marketing, and therefore the province's production has the potential to directly affect prices throughout Turkey. Afyon is the main egg-producing and exporting province in Turkey (Under, 2007). In 2006, there were 6,183,223 layers in Afyon province, producing 87,839 tons of eggs, representing $10.5 \%$ and $12 \%$ respectively of national totals (Turkish, 2006). The value of egg exports from Afyon province is $\$ 12$ millions, $17.6 \%$ of Turkey's total egg exports.

The economic effects of avian influenza were determined by comparing economic indicators during the period of avian influenza with those prior to the outbreak. It is expected that the results of the study will assist policy makers to establish compensation for producer losses and to develop solutions to problems of the egg industry.

Few studies have been published on the determination of the economic effects of avian influenza on poultry farming in Turkey. In this context, the present study helps to improve the understanding of the economic implications of avian influenza and will act as an important guide to further studies.

\section{MATERIAL AND METHODS}

The data used in this study were obtained using a questionnaire applied to egg farmers of Afyon province. In addition, evidence from similar studies conducted by other institutions and researchers were also utilized. Primary data was obtained during two 6-month periods: one in 2005, before the avian influenza outbreak, and the other in 2006, during the avian influenza outbreak. The two questionnaire periods cover different times of the year/production periods. In order to make a comparison on a same basis, it was necessary to account for any seasonal variation 
Demircan V, Yilmaz H, Dernek Z, Bal T, Gül M, Koknaroglu H
Economic Effects of Avian Influenza on Egg Producers in Turkey between the two sampling periods. Therefore, data were obtained for the same 6-month periods in 2005 and 2006, covering the period of December-May. Numerical data on costs and income obtained in the 6-month period of 2006 are adjusted for inflation.

Surveyed areas were selected following discussion with the personnel of the Ministry of Agriculture branch in Afyon province. Based on registrations of eggproducing farms, Afyon province, Başmakçi, Bolvadin, and Şuhut districts were selected as questionnaire sites due to the high proportion of egg-production in those areas. According to the registration data, there are 126 layer farms in the researched area. We initially hoped to survey all registered farms. However, some farms had closed their facilities due to avian influenza, whereas other farmers chose not to participate in the survey. The questionnaires were therefore completed by 75 farmers. Due to the wide range of sizes of the participating enterprises, farms were divided into three groups, according to the number of layers. The three groups included Group I: farms with 1-10,000 birds (37 farms); Group II: farms with 10,001-30,000 birds (21 farms); and Group III: farms with more than 30,001 birds (17 farms). Information obtained from the farmers by questionnaire were evaluated using Microsoft Excel program. The data were analyzed using the General Linear Model procedure of SAS, and PDIFF statements were used to compare farm groups.

Depreciation of buildings, machinery, and livestock was calculated. Depreciation rates were $2,4,1.5$, and $5 \%$ for concrete buildings, mud brick and wood buildings, stone buildings, and capital for machinery, respectively (Erkus et al., 1995). The following formulae were used to calculate the interest of capital invested in machinery and buildings (Kiral et al., 1999).

$$
\text { Interest }=\frac{\text { machinery or building value }}{2} * \text { int erest rate }
$$

Since end of year values were considered for machinery and building capital, real interest rates were used (Kadlec, 1985):

$$
i=\frac{(1+r)}{(1+f)}-1
$$

\footnotetext{
Where:

i : real interest rate

$r$ : nominal interest rate

$f$ : inflation rate (wholesale price index)
}

During the surveyed period, annual nominal interest was $23.5 \%$ and the inflation rate was $11.58 \%$; therefore, the real interest rate was found to be $10.68 \%$.

There is plural production activity on some of the participating farms. Therefore, some variable costs for machinery were common to those production branches. When distributing common costs, the proportion of machinery use by the egg-production part of the business was evaluated. Management expenses were assumed to be $3 \%$ of variable costs. When calculating the equivalence of labor cost of the family work, the wage rate of hired workers was used as basis. In cost calculations relative to the egg-production activity, since eggs are produced and sold on a daily basis, calculation of revolving fund interest was not required, because there is very short period between production and sale periods. (Kiral et al., 1999). However, revolving fund interest was calculated for the replacement pullet rearing period. Revolving fund interest was considered as half the interest rate (3.5 $\%$ ) applied by the Turkish Republic Agricultural Bank to variable costs for laying hen production credits.

Revenue from total sales of the egg-production activity constituted gross product value. By subtracting variable costs and production costs from gross product value, gross profit and net profit were obtained, respectively. Relative return was calculated by dividing gross product value by total production costs (Erkus et al., 1995; Rehber, 2005; Inan, 1998).

\section{RESULT AND DISCUSSION}

The costs of items of the layer farming production branch were classified and analyzed as fixed and variable costs. The cost of egg production in farms is given in Table 1 (during avian influenza) and 2 (before avian influenza). As shown in Tables 1 and 2, the production costs per farm in groups I and II was lower during the avian influenza outbreak than before. However, no significant difference in costs was found for group I. Production costs during the avian influenza period were 71,073.36, 20,4607.48, and 790,798.09 YTL for groups I, II, and II, as compared to 70,818.99, $23,7545.62$, and 97,9892.20 YTL, respectively, in the period before avian influenza ( $1 \mathrm{USD}=1.43 \mathrm{YTL}$ ). Since many laying hens were destroyed during the avian influenza period, the production costs of laying hen farms decreased. The number of hens destroyed per farm across the region was determined as 13,937, on average. The largest part of egg production costs in 


\begin{tabular}{|c|c|c|c|c|c|c|}
\hline \multirow[b]{2}{*}{ Cost Items } & \multicolumn{4}{|c|}{ Farm Groups } & \multirow[b]{2}{*}{ Group III } & \multirow[b]{2}{*}{$\%$} \\
\hline & Group I & $\%$ & Group II & $\%$ & & \\
\hline Feed & $46638.94 a$ & 65.62 & $147156.71 b$ & 71.92 & $544059.53 c$ & 68.80 \\
\hline Electricity & $511.73 a$ & 0.72 & $973.57 a$ & 0.48 & $9023.51 b$ & 1.14 \\
\hline Veterinarian- medication & $411.61 a$ & 0.58 & $461.09 a$ & 0.23 & $2684.51 b$ & 0.34 \\
\hline Cleaning-disinfecting & $92.72 \mathrm{a}$ & 0.13 & $247.55 a$ & 0.12 & $746.58 \mathrm{~b}$ & 0.09 \\
\hline Marketing & $92.82 a$ & 0.13 & $180.47 a$ & 0.09 & $949.89 b$ & 0.12 \\
\hline Packaging & $2293.71 a$ & 3.23 & $7602.05 b$ & 3.72 & $31229.25 c$ & 3.95 \\
\hline Machinery variable cost & 775.66a & 1.09 & $1214.61 a$ & 0.59 & $4925.19 b$ & 0.62 \\
\hline Other cost & $196.43 a$ & 0.28 & $411.75 a$ & 0.20 & $229.65 a$ & 0.03 \\
\hline A. Total Variable Costs & $51013.63 a$ & 71.78 & $158247.80 \mathrm{~b}$ & 77.34 & $593848.12 c$ & 75.09 \\
\hline Building capital interest & $830.73 a$ & 1.17 & $1649.88 a$ & 0.81 & $9008.06 b$ & 1.14 \\
\hline Building depreciation & $311.13 a$ & 0.44 & $617.93 a$ & 0.30 & $3373.81 \mathrm{~b}$ & 0.43 \\
\hline Building repair cost & $258.87 a$ & 0.36 & $410.07 a$ & 0.20 & $997.02 b$ & 0.13 \\
\hline Hiring charge of hen house & 233.05 & 0.33 & 147.40 & 0.07 & 0.00 & 0.00 \\
\hline Machinery capital interest & $812.31 a$ & 1.14 & $1449.08 a$ & 0.71 & $7141.90 \mathrm{~b}$ & 0.90 \\
\hline Machinery depreciation & $760.59 a$ & 1.07 & $1356.82 a$ & 0.66 & $6687.18 b$ & 0.85 \\
\hline Permanent labor force cost & $2872.79 a$ & 4.04 & $5245.43 a$ & 2.56 & $24467.29 b$ & 3.09 \\
\hline Chick growing cost & $12449.84 a$ & 17.52 & $30735.63 b$ & 15.02 & $127459.26 \mathrm{c}$ & 16.12 \\
\hline Management expenses $(A * \% 3)$ & $1530.41 a$ & 2.15 & $4747.43 b$ & 2.32 & $17815.44 c$ & 2.25 \\
\hline B. Total fixed costs & $20059.73 a$ & 28.22 & $46359.68 b$ & 22.66 & $196949.97 c$ & 24.91 \\
\hline Production costs $(A+B)$ & $71073.36 a$ & 100.00 & $204607.48 b$ & 100.00 & $790798.09 c$ & 100.00 \\
\hline
\end{tabular}

$1 \mathrm{USD}=1.43$ YTL. $a b c$ - Means with different superscripts in the same row differ $(P<0.05)$.

\begin{tabular}{|c|c|c|c|c|c|c|}
\hline \multirow[b]{2}{*}{ Cost Items } & \multicolumn{4}{|c|}{ Farm Groups } & \multirow[b]{2}{*}{ Group III } & \multirow[b]{2}{*}{$\%$} \\
\hline & Group I & $\%$ & Group II & $\%$ & & \\
\hline Feed & $46434.62 a$ & 65.57 & $176527.47 b$ & 74.31 & $722995.75 c$ & 73.78 \\
\hline Electricity & $369.28 a$ & 0.52 & $889.22 a$ & 0.37 & $6987.54 b$ & 0.71 \\
\hline Veterinary- medication & $411.18 a$ & 0.58 & $382.97 a$ & 0.16 & $2225.35 b$ & 0.23 \\
\hline Cleaning-disinfecting & $91.28 a$ & 0.13 & $106.84 a$ & 0.04 & $716.26 b$ & 0.07 \\
\hline Marketing & $117.48 a$ & 0.17 & $62.79 a$ & 0.03 & $827.45 b$ & 0.08 \\
\hline Packaging & $2473.85 a$ & 3.49 & $8833.40 a$ & 3.72 & $40641.18 b$ & 4.15 \\
\hline Machinery variable cost & $494.86 a$ & 0.70 & $1434.58 a b$ & 0.60 & $3909.25 b$ & 0.40 \\
\hline Other cost & $232.79 a$ & 0.33 & 151.46a & 0.06 & $153.30 \mathrm{a}$ & 0.02 \\
\hline A. Total Variable Costs & $50625.34 a$ & 71.49 & $188388.73 b$ & 79.31 & $778456.07 c$ & 79.44 \\
\hline Building capital interest & $775.82 a$ & 1.10 & $1436.86 a$ & 0.60 & $7127.70 b$ & 0.73 \\
\hline Building depreciation & $290.57 a$ & 0.41 & $538.15 a$ & 0.23 & $2669.55 b$ & 0.27 \\
\hline Building repair cost & $287.83 a$ & 0.41 & $339.41 a$ & 0.14 & $873.70 \mathrm{~b}$ & 0.09 \\
\hline Hiring charge of hen house & $222.43 a$ & 0.31 & $115.06 a b$ & 0.05 & $0.00 \mathrm{~b}$ & 0.00 \\
\hline Machinery capital interest & $648.06 a$ & 0.92 & $1353.67 a$ & 0.57 & $5750.73 b$ & 0.59 \\
\hline Machinery depreciation & $606.80 a$ & 0.86 & $1267.48 a$ & 0.53 & $5384.58 b$ & 0.55 \\
\hline Permanent labor force cost & $2077.63 a$ & 2.93 & $4888.17 a$ & 2.06 & $19952.66 b$ & 2.04 \\
\hline Chick growing cost & $13765.73 a$ & 19.44 & $33566.42 b$ & 14.13 & $136323.53 c$ & 13.91 \\
\hline Management expenses $(A * \% 3)$ & $1518.76 a$ & 2.14 & $5651.66 b$ & 2.38 & $23353.68 c$ & 2.38 \\
\hline B. Total fixed costs & $20193.64 a$ & 28.51 & $49156.89 b$ & 20.69 & $201436.13 c$ & 20.56 \\
\hline Production costs $(A+B)$ & $70818.99 a$ & 100.00 & $237545.62 b$ & 100.00 & $979892.20 c$ & 100.00 \\
\hline
\end{tabular}

abc - Means with different superscripts in the same row differ $(P<0.05)$.

the investigated farms consisted of variable costs in both periods. During the avian influenza period, variable costs were $71.78 \%$ in group I, $77.34 \%$ in group II, and $75.09 \%$ in group III, of the total costs. In comparison, in the period before avian influenza, variable costs represented $71.49 \%, 79.31 \%$, and $79.44 \%$, respectively, of the total costs. The main reason for the high proportion of variable costs is the cost of poultry feed. Between 2000 and 2006, the price of layer feed in Turkey increased in approximately 300\%
(State, 2007; Turkish, 2008). Feed is the main cost amongst the cost items of the investigated farms. During the period of avian influenza, the cost of feed represented $65.62 \%, 71.92 \%$, and $68.80 \%$ of the total costs for groups I, II, and III, respectively. During the period before the avian influenza outbreak, feed costs represented $65.57 \%, 74.31 \%$, and $73.78 \%$ of the total costs for groups I, II, and III, respectively. Similar results were found in other studies. Sariözkan and Sakarya (2006) reported that the share of feed cost in the total 


\section{Demircan V, Yilmaz H, Dernek Z, Bal T, Gül M, Koknaroglu H}

production cost was $67.46 \%$ for small farms, $70.89 \%$ for medium-size farms, and $70.05 \%$ for larger farms. Bayaner (1991) reported that the share of feed cost in the total cost was $67.82 \%$. Bostan (1980) found that the share of feed cost in the total production cost was $73.4 \%$

In order to minimize feed cost, which is the most significant economic cost in egg production, some measures are required. As Turkey produces little maize and soybeans, which are the basic components of chicken feeds, $30 \%$ of maize and $90 \%$ of soybean are imported (Ministry 2004). Higher premiums should be paid to incentive sufficient domestic maize and soybean production, thereby reducing dependence from imports. On the other hand, the other important cost item in the egg-production cycle is pullet rearing costs. The share of pullet rearing costs in the total production costs of groups I, II, and III were determined as $17.52 \%, 15.02 \%$, and $16.12 \%$ for the period of avian influenza and $19.44 \%, 14.13 \%$, and $13.91 \%$ for the period before avian influenza, respectively.

Income items during both survey periods are given in Tables 3 and 4. Gross product values per farm group during the avian influenza outbreak for farms of all sizes were significantly lower than in the period before avian influenza, as shown in Tables 3 and 4. Gross product values per farm for groups I, II, and III were $51,497.21,164,797.37$, and 678,762.76 YTL during the avian influenza period, down from 64,392.75, 244,511.97, and 1,134,545.69 YTL in the period before avian influenza, respectively. The reason for the lower gross product values during the avian influenza period could be the low egg prices obtained during that period. While the egg price during the avian influenza period was 0.059 YTL/egg, it was 0.088 YTL/egg before the avian influenza period (Registrations, 2006). During both periods, the most important part of gross product values consisted of egg sales. However, the income from egg sales as a proportion of the total gross values was lower during the avian influenza period. This can be explained by including in the gross product value, the value of the that were destroyed during the avian influenza period. Within the surveyed regions, infected and cull layers ( 60 weeks or older) were sacrificed, for which farmers received a compensation payment of 1.1 YTL/head from the Ministry of Agriculture and Rural Affairs $(O g, 2005)$. The compensation payments received by groups I, II, and III made up 10.99\%, 6.26\%, and $5.56 \%$, respectively, of the gross product value during the avian influenza period. The value of egg sales as a proportion of the total gross value product
Economic Effects of Avian Influenza on Egg Producers in Turkey

during the avian influenza period therefore accounted for $88.0 \%, 92.46 \%$, and $93.32 \%$ for groups I, II, and III, respectively. This compares to the $98.83 \%, 99.41 \%$, and $99.19 \%$ share of egg sales during the period before avian influenza.

\begin{tabular}{|c|c|c|c|}
\hline \multirow[b]{2}{*}{ Income Items } & \multicolumn{3}{|c|}{ Farm Groups } \\
\hline & Group I & Group II & Group III \\
\hline Egg sales & $45329.79 a$ & $152378.72 b$ & $633391.51 c$ \\
\hline Discarded hens sales & $401.17 a$ & $1294.65 a$ & $5620.09 b$ \\
\hline Destroyed hen value & $5658.06 a$ & $10311.88 a$ & $37752.56 \mathrm{~b}$ \\
\hline Manure sales & $108.20 a$ & $812.12 \mathrm{a}$ & $1998.60 \mathrm{~b}$ \\
\hline Total gross values product & $51497.21 a$ & $164797.37 b$ & $678762.76 c$ \\
\hline
\end{tabular}

Table 4. Egg sales income before avian influenza period in farms (YTL).

\begin{tabular}{lrrr}
\hline & \multicolumn{3}{c}{ Farm Groups } \\
\cline { 2 - 4 } Income Items & Group I & \multicolumn{1}{c}{ Group II } & Group III \\
\hline Egg sales & $64392.75 \mathrm{a}$ & $244511.97 \mathrm{a}$ & $1134545.69 \mathrm{~b}$ \\
Discarded hens sales & $679.63 \mathrm{a}$ & $1005.10 \mathrm{a}$ & $7401.31 \mathrm{~b}$ \\
Manure sales & $81.10 \mathrm{a}$ & $451.48 \mathrm{a}$ & $1818.91 \mathrm{~b}$ \\
Total gross values product & $65153.48 \mathrm{a}$ & $245968.54 \mathrm{a}$ & $1143765.91 \mathrm{~b}$ \\
\hline
\end{tabular}

$a b$ - Means with different superscripts in the same row differ $(P<0.05)$.

Gross profit, net profit, and relative return per farm and per hen are shown in Tables 5 and 6 . The results indicate that gross profit, net profit, and relative return per farm were lower for all farm sizes during the avian influenza period. The average gross profit per farm in groups I, II, and III was 483.58, 6,549.57, and 84,914.64 YTL during the avian influenza period, as compared to $14,528.13,57,579.81$, and 365,309.84 YTL in the period before avian influenza. Gross profit is an important criterion that determines the competitiveness of the production activity of the farm in terms of efficient resource-use (Rehber, 2005). According to the results, gross profit per farm increased as farm size increased, and larger farms were more successful in terms of management principles. While the average net profit per farm was found to be negative for all farm sizes during the avian influenza period, group I was the only group that presented negative net profit before the avian influenza period. The average net profit per farm for groups I, II, and III was -19576.14, -39,810.11, and $-112,035.33$ YTL during the avian influenza period and $-5665.51,8,422.92$, and 163,873.71 YTL during the period before avian influenza. Relative return is another criterion that measures the success of a commercial enterprise. Relative return refers to income which is 


\section{Demircan V, Yilmaz H, Dernek Z, Bal T, Gül M, Koknaroglu H}

Economic Effects of Avian Influenza on Egg Producers in Turkey gained from a cost to the business of each monetary unit (1 YTL). Relative return should be higher than 1 in order to ensure profitability. The relative return for groups I, II, and III was $0.72,0.81$, and 0.86 during the avian influenza period, and $0.92,1.04$, and 1.17 before the avian influenza period (Tables 5 and 6). The losses recorded by all farm size groups during the avian influenza period can be explained by the reduced prices caused by reduced demand during this period. Data of the Afyon Province Office of the Ministry of Agriculture and Rural Affairs show that 35 egg-producing farms closed down due to avian influenza (Ministry, 2006). In the period prior to avian influenza, only group I lost money, but farms in group II and III were profitable. It may be explained by the fact that, although farms in group I lost money, they continued to operate because the gross product value could compensate its entire variable cost. Producers' family labor salaries, interests, and building and machinery deprecation were calculated in the cost analysis, and were included in the production costs. In other words, even when producers lost money, production continued to be economically rational because they received compensation for their labor and own capital.

\begin{tabular}{lrrr}
\hline \multicolumn{4}{l}{$\begin{array}{l}\text { Table 5. Gross profit, net profit, and relative return during avian } \\
\text { influenza period in farms. }\end{array}$} \\
\hline & \multicolumn{4}{c}{ Farm Groups } \\
\cline { 2 - 4 } Values (YTL/ Farms) & Group I & Group II & Group III \\
\hline Gross product value & $51497.21 \mathrm{a}$ & $164797.37 \mathrm{~b}$ & $678762.76 \mathrm{c}$ \\
Variable costs & $51013.63 \mathrm{a}$ & $158247.80 \mathrm{~b}$ & $593848.12 \mathrm{c}$ \\
Production costs & $71073.36 \mathrm{a}$ & $204607.48 \mathrm{~b}$ & $790798.09 \mathrm{c}$ \\
Gross profit & $483.58 \mathrm{a}$ & $6549.57 \mathrm{a}$ & $84914.64 \mathrm{~b}$ \\
Net profit & $-19576.14 \mathrm{a}$ & $-39810.11 \mathrm{a}$ & $-112035.33 \mathrm{~b}$ \\
Relative return & $0.72 \mathrm{a}$ & $0.81 \mathrm{~b}$ & $0.86 \mathrm{~b}$ \\
Values (YTL/hen) & \multicolumn{4}{|c}{} \\
Gross product value & $9.99 \mathrm{a}$ & $9.30 \mathrm{a}$ & $9.18 \mathrm{a}$ \\
Variable costs & $9.90 \mathrm{a}$ & $8.93 \mathrm{a}$ & $8.03 \mathrm{a}$ \\
Production costs & $13.79 \mathrm{a}$ & $11.54 \mathrm{ab}$ & $10.70 \mathrm{~b}$ \\
Gross profit & $0.09 \mathrm{a}$ & $0.37 \mathrm{a}$ & $1.15 \mathrm{a}$ \\
Net profit & $-3.80 \mathrm{a}$ & $-2.25 \mathrm{~b}$ & $-1.52 \mathrm{~b}$ \\
Relative return & $0.72 \mathrm{a}$ & $0.81 \mathrm{~b}$ & $0.86 \mathrm{~b}$ \\
\hline
\end{tabular}

$a b c$ - Means with different superscripts in the same row differ $(P<0.05)$.

Cost and income factors per farm were analyzed on per hen basis. Gross profit per hen during the avian influenza period was lower than in the period before avian influenza. Gross profit per hen during the avian influenza period was determined as $0.09,0.37$, and 1.15 YTL for groups I, II, and III, as compared to 2.81, 3.01, and $4.08 \mathrm{YTL}$, respectively, in the period before avian influenza. Gross profit per hen increased as farm size increased during both studied periods. Gross profit per hen was determined to be negative for all farm groups during the avian influenza period, but negative only for group I before avian influenza. Net profit per hen during the avian influenza period was found to be $-3.80,-2.25$, and -1.52 YTL for groups I, II, and III, respectively, whereas it was $1.10,0.44$, and $1.83 \mathrm{YTL}$ before avian influenza. According to these results, it can be said that losses per hen decreased as farm size decreased during the avian influenza period, but increased in the period before avian influenza (Tables 5 and 6).

\begin{tabular}{lrrr}
\hline \multirow{2}{*}{$\begin{array}{l}\text { Table 6. Gross profit, net profit and relative return before avian } \\
\text { influenza period in farms. }\end{array}$} \\
\cline { 2 - 4 } Values (YTL/ Farms) & Group I & Group II & Group III \\
\cline { 2 - 4 } Gross product value & $65153.48 \mathrm{a}$ & $245968.54 \mathrm{a}$ & $1143765.91 \mathrm{~b}$ \\
Variable costs & $50625.34 \mathrm{a}$ & $188388.73 \mathrm{~b}$ & $778456.07 \mathrm{c}$ \\
Production costs & $70818.99 \mathrm{a}$ & $237545.62 \mathrm{~b}$ & $979892.20 \mathrm{c}$ \\
Gross profit & $14528.13 \mathrm{a}$ & $57579.81 \mathrm{a}$ & $365309.84 \mathrm{~b}$ \\
Net profit & $-5665.51 \mathrm{a}$ & $8422.92 \mathrm{a}$ & $163873.71 \mathrm{~b}$ \\
Relative return & $0.92 \mathrm{a}$ & $1.04 \mathrm{~b}$ & $1.17 \mathrm{c}$ \\
Values (YTL/hen) & \multicolumn{4}{|c}{} \\
Gross product value & $12.62 \mathrm{a}$ & $12.85 \mathrm{a}$ & $12.78 \mathrm{a}$ \\
Variable costs & $9.81 \mathrm{a}$ & $9.84 \mathrm{a}$ & $8.70 \mathrm{a}$ \\
Production costs & $13.72 \mathrm{a}$ & $12.41 \mathrm{ab}$ & $10.95 \mathrm{~b}$ \\
Gross profit & $2.81 \mathrm{a}$ & $3.01 \mathrm{a}$ & $4.08 \mathrm{a}$ \\
Net profit & $-1.10 \mathrm{a}$ & $0.44 \mathrm{~b}$ & $1.83 \mathrm{c}$ \\
Relative return & $0.92 \mathrm{a}$ & $1.04 \mathrm{~b}$ & $1.17 \mathrm{c}$ \\
\hline abc - Means with different superscripts in the same row differ \\
(P<0.05).
\end{tabular}

Egg costs and profit margins of the participating farms during and before the avian influenza period are shown in Tables 7 and 8 . Egg cost per bird was calculated by subtracting the value of culled hens, destroyed hens, and manure sales from average production costs per farm, and the residual value was divided by the amount of total egg production. Then, profit margins were calculated by subtracting the cost of producing 1 egg from the egg sales price. The results indicate that the cost of egg production dropped during the avian influenza period for all farm size groups. Prior to avian influenza, production costs were offset against total values of hen and manure sales. During the avian influenza period, production costs were offset against discarded hen values, manure sales, and the compensation received for hens that were culled. The average cost of one egg during the avian influenza period was $0.088,0.075$, and 0.069 YTL for groups I, II, and III, respectively, as compared to $0.095,0.085$, and 0.074 YTL before the avian influenza period. These results indicate that egg cost decreased as farm size increased in both periods. When both studied periods were compared in terms of profit margins, it was determined that the period before avian influenza was 


\section{Demircan V, Yilmaz H, Dernek Z, Bal T, Gül M, Koknaroglu H}

Economic Effects of Avian Influenza on Egg Producers in Turkey

more profitable. The calculated profit margin was negative for all farm size groups during the avian influenza period. In comparison, the profit margin was negative for group I, but positive for groups II and III before avian influenza. Since demand for eggs dropped during the avian influenza period, the price of eggs also dropped, causing economic losses for farms. The results indicate that small producers experienced greater losses than larger producers. The profit margin for groups I, II, and III were $-0.029,-0.016$, and -0.010 YTL/egg during the avian influenza period, and 0.007 , 0.003 , and $0.014 \mathrm{YTL} /$ egg before avian influenza, respectively (Tables 7 and 8 ).

\section{CONCLUSIONS}

This study determined the economic effects of avian influenza by comparing economic indicators of 2 periods of study - before and during the avian influenza period. The study location of Afyon Province has a significant role in egg production and marketing in Turkey. According to the results, while net profit and profit margins during the avian influenza period were found to be negative for all farm size groups, only the smallest producers (group I) made a loss in the period prior to avian influenza. It was also found that larger farms suffered lower economic losses than small farms during the avian influenza period. Larger farms were also more profitable than smaller producers during the period before avian influenza. For this reason, new policies should be developed, focusing on enhancing farm capacity. In addition, in order to reduce the cost of feed for producers, additional support should be provided for the domestic production of raw materials of poultry feed (maize, soybean, sunflower, etc.). In order to compensate the losses of egg farmers due to avian influenza, feed and electricity inputs should be subsidized and low-interest credit facilities should be provided. In addition to these economic measures, it is necessary to create in Turkey a network to address animal health and diseases, especially those of layers. An important factor in establishing such a network would be the provision of sufficient resources for the creation and staffing of an animal health laboratory.

\section{REFERENCES}

Bayaner A. Economic analyses of laying hen farms in Çorum Province. Ankara: Research Institute for Agricultural Economics; 1999. Publications 23.

Bostan M. Economic structure of main method problems in laying hen farms in Istanbul Province [thesis]. Beyazit: Istanbul University, the Faculty of Veterinary, Department of Biostatistics and Animal Managerial Economics; 1980.

\begin{tabular}{lrrr}
\hline Table 7. Egg cost and margin of profit in farms during avian influenza period. & & Farm Groups \\
\cline { 2 - 3 } & \multicolumn{1}{c}{ Group I } & Group II & Group III \\
\hline A. Production costs (YTL/ farm) & $71073.36 \mathrm{a}$ & $204607.48 \mathrm{~b}$ & $790798.09 \mathrm{c}$ \\
B Discarded hens sales (YTL/ farm) & $401.17 \mathrm{a}$ & $1294.65 \mathrm{a}$ & $5620.09 \mathrm{~b}$ \\
C. Destroyed hen value (YTL/ farm) & $5658.06 \mathrm{a}$ & $10311.88 \mathrm{a}$ & $37752.56 \mathrm{~b}$ \\
D. Manure sales (YTL/ farm) & $108.20 \mathrm{a}$ & $812.12 \mathrm{a}$ & $1998.60 \mathrm{~b}$ \\
E. Number of eggs per farm during laying period & $737420 \mathrm{a}$ & $2566157 \mathrm{~b}$ & $10781262 \mathrm{C}$ \\
F. Egg cost (YTL/egg) (A-B-C-D/E) & $0.088 \mathrm{a}$ & $0.075 \mathrm{ab}$ & $0.069 \mathrm{~b}$ \\
G. Egg cost (YTL/kg) & $1.408 \mathrm{a}$ & $1.198 \mathrm{ab}$ & $1.106 \mathrm{~b}$ \\
H. Egg sales price (YTL/egg) & $0.059 \mathrm{a}$ & $0.059 \mathrm{a}$ & $0.059 \mathrm{a}$ \\
I. Margin of profit (YTL/egg) (H-F) & $-0.029 \mathrm{a}$ & $-0.016 \mathrm{ab}$ & $-0.010 \mathrm{~b}$ \\
\hline
\end{tabular}

$a b c$ - Means with different superscripts in the same row differ $(P<0.05)$.

\begin{tabular}{lrrr}
\hline Table 8. Egg cost and margin of profit in farms before avian influenza period. & & Farm Groups \\
\cline { 2 - 3 } & \multicolumn{1}{c}{ Group I } & Group II & Group III \\
\hline A. Production costs (YTL/ farm) & $70818.99 a$ & $237545.62 \mathrm{~b}$ & $979892.20 \mathrm{c}$ \\
B. Hen discarded sales (YTL/ farm) & $679.63 \mathrm{a}$ & $1005.10 \mathrm{a}$ & $7401.31 \mathrm{~b}$ \\
C. Manure sales (YTL/ farm) & $81.10 \mathrm{a}$ & $1818.91 \mathrm{~b}$ \\
D. Number of eggs per farm during laying period & $735682 \mathrm{a}$ & $451.48 \mathrm{a}$ & $13036864 \mathrm{~b}$ \\
E. Egg cost (YTL/egg) (A-B-C /D) & $0.095 \mathrm{a}$ & $2764237 \mathrm{a}$ & $0.074 \mathrm{~b}$ \\
F. Egg cost (YTL/kg) & $1.524 \mathrm{a}$ & $0.085 \mathrm{ab}$ & $1.191 \mathrm{~b}$ \\
G. Egg sales price (YTL/egg) & $0.088 \mathrm{a}$ & $1.367 \mathrm{ab}$ & $0.088 \mathrm{a}$ \\
H. Margin of profit (YTL/egg) (G-E) & $-0.007 \mathrm{a}$ & $0.088 \mathrm{a}$ & $0.014 \mathrm{~b}$ \\
\hline
\end{tabular}

$a b c$ - Means with different superscripts in the same row differ $(P<0.05)$. 
Demir C. Protection ways from avian influenza. Journal of Science and Utopia 2006; 140(12):19-22.

Erkuş A, Bülbül M, Kiral T, Açil A.F, Demirci R. Agricultural economics. Ankara: Agricultural Faculty of Ankara University; 1995.

Food and Agriculture Organization; 2006. Available from: http:// www.fao.org/

Inan IH. Agricultural economics and management. Tekirdag: Agricultural Faculty of Tekirdağ, 1998.

Kadlec CE. Farm Management, decisions, operation, control. London: Prentice-Hall; 1985.

Kiral T, Kasnakoğlu H, Tatlidil F, Fidan $H$ and Gündoğmuş E. data base guide and production cost methodology for agricultural products. Ankara: Agricultural Economics Research Institute; 1999. Publication 37.

Ministry of Agriculture and Rural Affaires. II. Conclusion Report of Agricultural Commission of Turkey. Ankara; 2004.

Ministry of Agriculture and Rural Affaires. Reports of Afyon Province Office of the Ministry of Agriculture and Rural Affaires. Afyon; 2006.

Registrations ff Başmakçi Laying Hen Agricultural Development Cooperative, Başmakçi. Afyon; 2006.

Rehber E. Declaration regarding the destruction of ex-layer hens and supporting of growers [Declaration 2006/4]. Bursa: Agricultural Management and Planning; 2005. Official Gazette 26059.

Sariozkan S, Sakarya E. The profitability and productivity analyses of layer hen enterprises in Afyon Province. Journal of Lalahan Livestock Research Institute 2006; 46(1):29-44.

State Planning Organization. Animal Husbandry Commission Report. Ankara; 2001.

State Planning Organization. Animal Husbandry Commission Report. Ankara; 2007.

Statistical Analysis Systems) User's guide. 8th ed. Raleigh: SAS Institute; 1999.

Turkish Egg Producers Association [cited 2008 set 09]. Available from: http://www.yumbir.org.tr/.

Turkish Statistical Institute. Agricultural structure: production, price, value. Ankara; 2006.

Under secretariat of Foreign Trade. Registrations of Under secretariat of Foreign Trade. Ankara; 2007.

Yenen OS. Dimension of biological and social of avian influenza. Journal of Science and Utopia 2006; 140(12):4-11. 